\title{
Review
}

\section{The hypersensitive response and the induction of cell death in plants}

\author{
Jean-Benoit Morel and Jeffery L. Dangl \\ Department of Biology, Coker Hall 108, CB 3280, University of North Carolina, \\ Chapel Hill, NC 27599-3280, USA tel: +1 (919) 962-5624; fax: +1 (919) 962- \\ 1625; e-mail: dang|@email.unc.edu
}

Received 4.4.97; revised 30.6.97; accepted 14.7.97

Edited by B.A. Osborne

\begin{abstract}
The hypersensitive response, or HR, is a form of cell death often associated with plant resistance to pathogen infection. Reactive oxygen intermediates and ion fluxes are proximal responses probably required for the HR. Apoptosis as defined in animal systems is, thus far, not a strict paradigm for the HR. The diversity observed in plant cell death morphologies suggests that there may be multiple pathways through which the HR can be triggered. Signals from pathogens appear to interfere with these pathways. HR may play in plants the same role as certain programmed cell deaths in animals with respect to restricting pathogen growth. In addition, the HR could regulate the defense responses of the plant in both local and distant tissues.
\end{abstract}

Keywords: HR; oxidative burst; resistance; biotrophic and necrotrophic pathogens; suppression and negation of plant defenses

Abbreviations: HR, Hypersensitive Response; XR, ion fluxes; ROls, Reactive Oxygen Intermediates; SA, Salicyclic Acid; SAR, Systemic Acquired Resistance

\section{Introduction}

Plants have evolved sophisticated and efficient mechanisms to prevent the invasion of their tissues by pathogens, and disease rarely occurs. One common feature of disease resistance is the rapid development of cell death at and immediately surrounding infection sites, called the Hypersensitive Response, or HR (Agrios, 1988; Goodman and Novacky, 1994). The HR can be triggered by a wide variety of pathogens and occurs within a few hours following pathogen contact. It is important to note that what plant pathologists traditionally call necrosis is not equivalent to necrosis in animal systems (by opposition to apoptosis). Rather, necrosis historically denoted a macroscopic phenomenon without mechanistic connotations. Cell death is also visible in the development of disease symptoms, but occurs temporally much later accompanying pathogen ingress. In this review, we will refer to $\mathrm{HR}$ as the development of cell death as a consequence of disease resistance, and to necrosis as the development of cell death during the process of disease. Note that this use of terms is still not intended to necessarily connote mechanistic differences.

The HR is often conditioned by the presence in the pathogen of an avirulence (avr) gene, the direct or indirect product of which is recognized by a plant possessing the corresponding resistance $(R)$ gene. An interaction leading to disease is termed compatible and, when resistance is effective, the interaction is called incompatible. This specific pathogen recognition accounts for many, but not all, plant disease resistances (Dangl, 1995; Staskawicz et al, 1995). The simplest mechanistic model is that the avr gene encodes a ligand that is recognized by the product of the matching $R$ gene which then triggers the HR and disease resistance (Bent, 1996). In addition, molecules from the pathogen called elicitors are able to trigger HR (Ebel and Cosio, 1994). Plant receptors are also thought to be involved in recognition of these elicitors (Nürnberger et al, 1994; Umemoto et al, 1997).

Subsequent to recognition, biochemical and metabolic plant modifications are well conserved among different plantmicrobe interactions (Hammond-Kosack and Jones, 1996). Following pathogen recognition, constitutively expressed signal transduction pathways are engaged. A large set of inducible genes, commonly known as defense related genes, are expressed as resistance develops. They include enzymes involved in the synthesis of anti-microbial compounds called phytoalexins, structural proteins incorporated into the cell wall (Bradley et al, 1992), and the pathogenesis related (PR) proteins, some of which have known anti microbial activities (Schlumbaum et al, 1986). The induction of these defense genes is not specific to plant-pathogen interactions. Abiotic treatments and physical stresses have been shown to activate them (Brederode et al, 1990), and they often are expressed during normal development (Samac and Shah, 1991; Dangl, 1992).

While the mechanisms of cell death in animals have been studied in great detail, our understanding of the mechanism of cell death in plants is still poor. In plants, cell death is also invoked developmentally during xylogenesis, senescence, and reproduction (Hatfield and Bennett, 1997; Fukuda, 1997; Greenberg, 1996; Jones and Dangl, 1996). Here we will address the following key questions:

- Is the HR programmed?

- What is the cytological morphology of HR?

- How is the HR induced? 
- Has the HR a causal role in disease resistance?

- Are there mechanistic differences between the cell death associated with the HR and that associated with disease?

As the HR may be driven by signals from both the host and the pathogen, a particular emphasis is given to the context of plant-microbe interaction in which this phenomenon occurs.

\section{Is the HR programmed?}

Several lines of evidence suggest that the HR results from the activation of an intrinsic program:

(1) A large class of plant mutants, called disease lesion mimics, show spontaneous cell death resembling HR or disease symptoms (Dangl et al, 1996). In a subset of disease lesion mimics (Isd and acd mutants), the development of cell death is associated with the induction of defense-related markers such as callose deposition, PR gene expression and heightened resistance to otherwise virulent pathogens (Dietrich et al, 1994; Greenberg et al, 1994). Therefore these mutants are likely to represent defects in the pathway leading to the HR and disease resistance and not simply metabolic perturbations triggering cell death. Two subclasses of $I s d$ mutants were established based on the phenotypes observed. First, initiation mutants display lesions which are limited in size (e.g. the Isd5 Arabidopsis mutant; Dietrich et al, 1994), and probably represent defects in the triggering of cell death. Second, propagation class mutants express lesions which, once initiated, spread and usually engulf the entire leaf (see Isd1 and IIs 1 below). These propagation mutants have been hypothesized to represent defects in mechanisms that negatively control HR (Walbot et al, 1983; Dietrich et al, 1994). Recently, Hu et al (1996) demonstrated that some maize lesion mimics are caused by mutations in the rust disease resistance gene $R p 1$, indicating that a mutant form of an $R$ gene can also trigger pathogen-independent cell death.

(2) The HR requires active plant gene transcription and translation (He et al, 1994). Therefore it appears that the HR is an active process, genetically controlled, and does not necessarily or only result from damage caused by the pathogen.

(3) The expression of various transgenes in the plant sometimes results in the development of cell death reminiscent of HR (Dangl et al, 1996; Mittler and Lam, 1996). Despite the fact that these phenotypes could be due to perturbation of plant cellular homeostasis, it is interesting to note that in some cases the overexpressed transgene was previously implicated in plant-pathogen interactions. For instance, proton pump ATPases are active in the early steps of many defense responses (Atkinson and Baker, 1989; see below), and overexpression of a bacterial light-driven proton pump gene in tobacco results in the formation of lesions (Mittler et al, 1995).
(4) There is no requirement for the presence of a living pathogen to trigger the HR. For example, certain purified elicitors can induce many of the physiological changes occurring during disease resistance (Nürnberger et al, 1994) and lesions resembling the $\mathrm{HR}$ ( $\mathrm{He}$ et al, 1993; May et al, 1996). Therefore the destructive potential of an active pathogen is not necessary. Purified pathogen phytotoxins can have similar effects (Gilchrist, 1997; Levine et al, 1996).

Thus, there are plant genes and signaling programs controlling the HR. The analysis of model systems, such as cell death control mutants and transgenic plants showing spontaneous lesions, is likely to provide useful information regarding the plant components involved during the $H R$, in absence of pathogen interference.

\section{Morphologies of HR}

In most studied pathosystems, pathogen infection is nonsynchronous. This renders the chronological ordering of the cytological events leading to HR difficult. Several systems are utilized to describe the development of HR in living plant tissues where individual infection events can be followed. One well characterized system is the interaction between the biotrophic fungus Uromyces vignae and cowpea. At $15 \mathrm{~h}$ after inoculation during an incompatible interaction, Chen and Heath (1991) observed the following sequence of cytological events: (i) migration of the nucleus to the site of fungal penetration and intense cytoplasmic streaming, (ii) cessation of cytoplasmic streaming, Brownian motion of the organelles, condensation of the nucleus, accumulation of granules at the periphery of the cytoplasm, shrinkage of the protoplast and (iii) collapse of the cytoplasm and death of the infected cell. Similar cytological changes were observed in the interaction between Erysiphe graminis f.sp hordei and barley plants carrying the $\mathrm{Mla}_{12}$ resistance gene (Bushnell, 1981). These changes were not observed in an isogenic susceptible plant, indicating that they are under the control of the $M \mathrm{Ia}_{12}$ resistance gene. The timing of these events has been precisely established using video microscopy during an incompatible interaction between Phytophthora infestans and potato. Only $26 \mathrm{~s}$ are necessary for plant cell collapse and death, and death of the fungus follows $20 \mathrm{~s}$ later (Freytag et al, 1994). Such rapid responses could make detection of intermediate steps almost impossible using fixed tissues.

As yet there is no specific molecular or cytological marker in plants which would allow clear discrimination between necrosis and the HR. Therefore recent investigations have often applied criteria established in animal systems. Some characteristics of animal apoptosis have been shown to occur in plants during interactions with pathogens or purified elicitors. Levine et al (1996) detected plasma membrane blebbing, cell shrinkage, condensation of both the cytoplasm and nucleus, and structures that might be interpreted as apoptotic bodies during the HR triggered by bacterial pathogens, but not in susceptible tissues. However, they did not detect DNA laddering. Fragmentation of nuclear DNA (but no DNA laddering) was observed in resistant tobacco plants infected with TMV 
(Mittler et al, 1996). In contrast Ryerson and Heath (1996) demonstrated the presence of oligonucleosomal fragments during an incompatible interaction between Uromyces vignae and cowpea. HR-induced endonucleases may play a role in this process (Mittler and Lam, 1995). Finally, apoptotic bodies were also detected in isolated protoplasts from susceptible plants treated with the AAL-toxin (Wang et al, 1996). Because there is no known system in plants capable of scavenging such corpses, this finding begs the question of how the plant disposes of dead cell debris.

Thus there is so far no clear correlation between one particular morphology of cell death and either the HR or disease symptoms. There are only a few examples correlating disease symptoms with cytologically defined necrosis (as defined in animal systems) and resistance with apoptosis-like cell death (Levine et al, 1996). In other cases, resistance is associated with cytological changes reminiscent of animal necrosis (Bestwick et al, 1995). Although cell death in plants could functionally play the same role as in animals, it may be that the mechanisms underlying this process evolved differently (Mittler and Lam, 1996). Moreover, signals from both the plant and the pathogen can intervene to affect progression to cell death. Thus assessing cell death in the context of the interaction in which it occurs may facilitate our understanding.

\section{Inducers, effectors and regulators of the HR}

Some recent reviews provide detailed information concerning the induction and signal transduction leading to disease resistance (Bent, 1996; Hammond-Kosack and Jones, 1996) and here we will only review recent findings relevant to our understanding of the HR. At least two steps are necessary to induce the HR: recognition of the pathogen and transduction of the perceived signal(s) to the effector(s) of cell death (Figure 1).

\section{How is the HR induced?}

The specific pathogen recognition model suggests that the first event in triggering the HR could be the direct recognition of the pathogen avr gene product by the corresponding plant $R$ gene product. Recent evidence indicates that there is such a direct interaction between the tomato Pto resistance gene product and the product of the avirulence gene avrPto from Pseudomonas syringae pv tomato (Scofield et al, 1997; Tang et al, 1997). To date, the analysis of the sequences of the different cloned resistance genes suggests that this possible type of direct interaction may not only happen in the plasma membrane but also in the cytoplasm (Jones, 1997) and in the nucleus (Leister et al, 1996; Van den Ackerveken et al, 1996).

The earliest changes observed following pathogen recognition are an oxidative burst, resulting in production of Reactive Oxygen Intermediates (ROls) (Baker and Orlandi, 1995; Levine et al, 1994; May et al, 1996) and rapid ion fluxes across the plasma membrane, termed the XR (Atkinson and Baker, 1989). There is some debate concerning the nature of the ROls involved. While recent studies suggest that $\mathrm{H}_{2} \mathrm{O}_{2}$ is sufficient to induce soybean cell death (Levine et al, 1994, 1996), compelling evidence indicates that superoxide radical $\left(\mathrm{O}_{2}{ }^{-}\right)$is the key $\mathrm{ROI}$ in triggering cell death in the Arabidopsis Isd1 mutant (Jabs et al, 1996). Superoxide is weakly diffusable and could be dismutated to $\mathrm{H}_{2} \mathrm{O}_{2}$ or other diffusable, toxic ROls, which then can cross or damage the plasma membrane. A membrane NADPH oxidase analogous to that found in mammalian neutrophils may be involved in this process (Groom et al, 1996). ROls could also act as a signal via the production of lipid peroxides (May et al, 1996; Mehdy, 1994).

The $\mathrm{XR}$ is characterized by an uptake of $\mathrm{Ca}^{2+}$ (Levine et al, 1996) and export of $\mathrm{Cl}^{-}$and $\mathrm{K}^{+}$driven by $\mathrm{H}^{+}$-ATPases, resulting in alkalinization of the cytoplasm (Atkinson and Baker, 1989).

There is still some debate concerning the order in which these responses occur. In a study using cultured parsley cells and a glycoprotein elicitor (which does not trigger cell death under these conditions), Jabs et al (1997) established that the XR precedes the oxidative burst. In contrast, using a different system (soybean cultured cells treated with $\mathrm{H}_{2} \mathrm{O}_{2}$ ), Levine et al (1996) demonstrated that the oxidative burst precedes and stimulates a rapid influx of $\mathrm{Ca}^{2+}$, leading to cell death. Glazener et al (1996) showed that a mutant of Pseudomonas syringae pv syringae unable to trigger either an HR on tobacco leaves or cell death in cell suspensions was still able to elicit a normal XR and oxidative burst in cell suspensions. Thus the oxidative burst and the XR are probably necessary but may not be generally sufficient in each system to initiate the cell death process.

Little is known about the molecular events following the initial recognition of the avirulence signal and the earliest cellular responses described above (reviewed by Hammond-Kosack and Jones, 1996; Low and Merida, 1995). Large surveys for mutants in loci necessary for normal $R$ gene function have been undertaken (Freialdenhoven et al, 1994, 1996; Hammond-Kosack et al, 1994). Using such a genetic approach, Salmeron et al (1996) identified a gene, Prf, necessary for Pto function. Prf encodes a protein with leucine-zipper, nucleotide binding and leucine-rich repeat motifs, as are found in a number of disease resistance genes (Bent, 1996). Pto was previously found to encode a cytoplasmic serine-threonine kinase (Loh and Martin, 1995; Martin et al, 1993), suggesting that kinase cascades may be involved in triggering HR. By using the yeast two-hybrid system, Zhou et al (1995) have shown that a serinethreonine kinase, Pti, is phosphorylated by Pto and that overexpression of Pti is sufficient for further signaling of the $\mathrm{HR}$ in transgenic tobacco.

Genetic approaches have proven useful to further analyze the signal transduction pathways leading to the $\mathrm{HR}$. In barley, gene interaction studies have shown that a mutant allele of a gene required for Mla-based resistance (rar1; Freialdenhoven et al, 1994) does not abolish Mlgbased resistance at the macroscopic level. Interestingly, at the microscopic level, the rar1 mutation modifies the Mlg resistance phenotype. This is manifested by an increase of fungal penetration events in rar1/Mlg plants compared to Rar1/Mlg plants. However, although rar1 suppresses the 
HR phenotype of the Mla-mediated resistance, it does not suppress the cell death response of the Mlg-mediated resistance (Peterhänsel et al, 1997). This result suggests that, in barley, alternative routes leading to HR exist and may or may not converge (Figure 2A). Similarly, Parker et al (1996) isolated an Arabidopsis mutant, eds-1, suppressing the action of several different $R$ genes directed against isolates of the biotrophic pathogen Peronospora parasitica, but not to an incompatible bacterial pathogen. Thus eds-1 defines a function upstream from a possible convergence of bacterial and fungal resistance gene signaling pathways. In contrast, the Arabidopsis ndr-1 mutant is impaired in resistance against both bacteria and Peronospora (Figure
2B; Century et al, 1995). Ndr could thus represent a downsteam step in signaling, after the convergence of pathways specific to fungal and bacterial pathogens.

\section{Effectors of cell death}

The nature of the effectors of HR remains elusive. Some components of the defense response are potentially toxic for the plant cell (e.g. ROls, phytoalexins, SA) (see Ward et al, 1991 concerning SA) and they could participate directly in cell death (Figure $3 \mathrm{~A}$ ). ROls can cause loss of cell integrity and viability because of their elevated reactivity towards membrane lipids, proteins and nucleic acids (Baker and

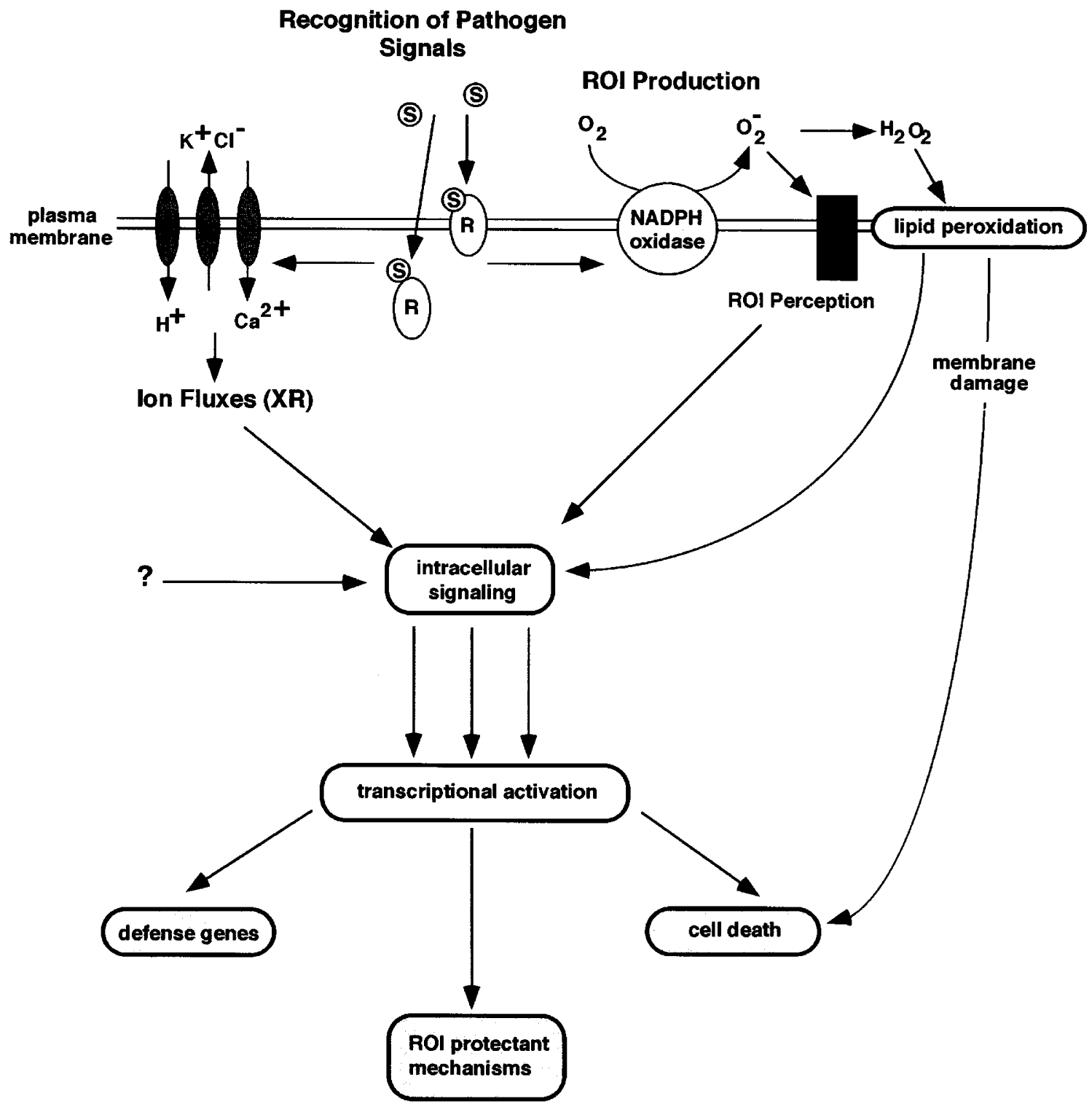

Figure 1 A simplistic picture of the transduction pathways leading to the HR. After initial recognition of the pathogen signal (S) via an extra- or intracellular receptor ( $\mathrm{R}$; the product of a plant $R$ gene or an elicitor receptor), an oxidative burst and ion fluxes (XR) trigger intracellular signaling (mediated by $\mathrm{ROI}$ perception, kinase/phosphatase cascades, lipid peroxidation), which in turn results in the activation of defense responses. These defense responses are composed of defense gene activation (structural proteins, phytoalexins biosynthesis genes, anti-fungal proteins) and cell death (endonucleases, proteases). Cellular protectant mechanisms are also induced in order to control the extent of the cell death (superoxide dismutases, catalases, glutathione peroxidases and S-transferase) 
Orlandi, 1995). Serine and cysteine proteinases and endonucleases may also be part of a complex machinery set in motion during the HR (Levine et al, 1996; Mittler and Lam, 1995). To date, plant homologues to animal caspases have not been described.
However, as some of the induced defense molecules appear well after the first signs of cell death, they are probably not determinants of HR (Goodman and Novacky, 1994; Schröder et al, 1992). An Arabidopsis mutant (pad3) deficient in the synthesis of the major phytoalexin

A

B
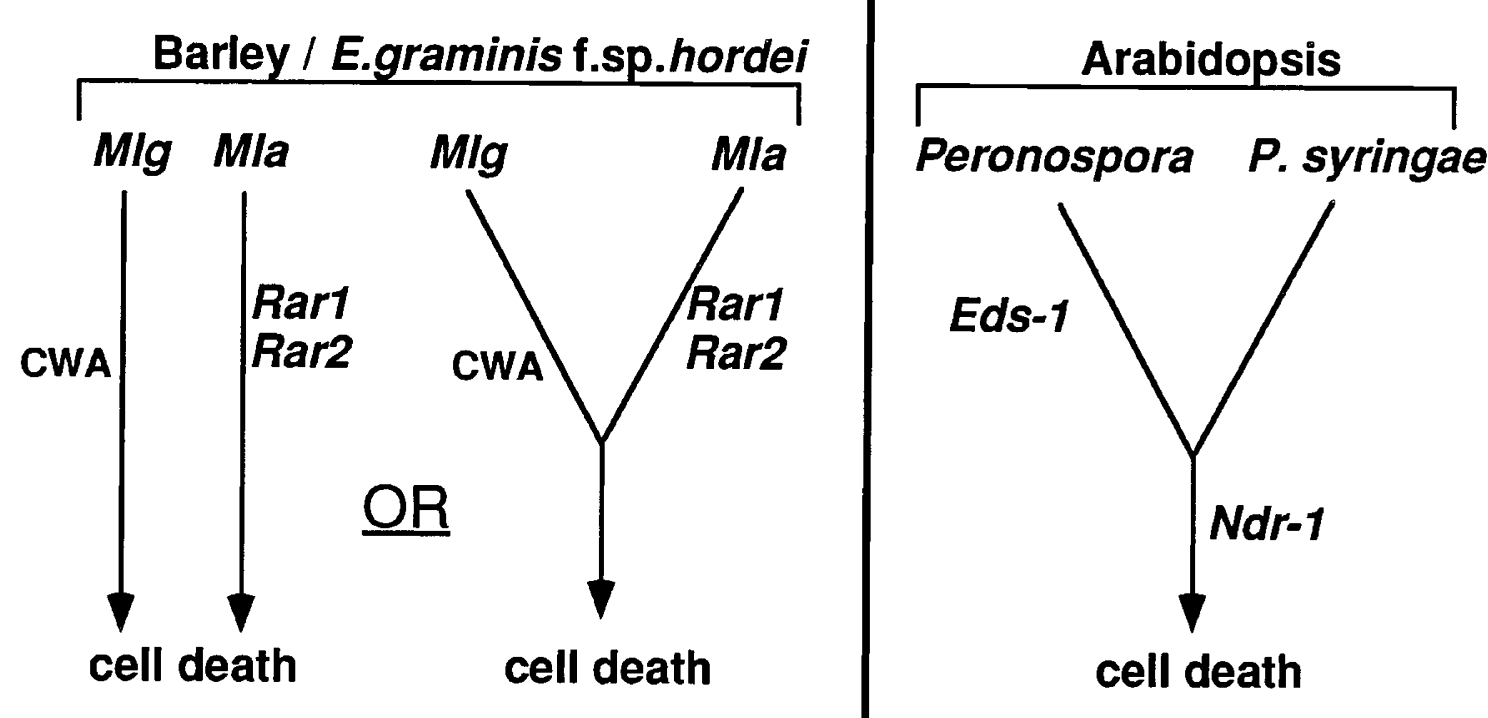

Figure 2 Genetic dissection of the pathways leading to the HR. (A) The Mlg and Mla based resistances of barley could function independently and lead to plant cell death. Alternatively, the Mlg and Mla pathways could converge. A requirement for the Rar1 and Rar2 products for Mla-mediated cell death, but not Mlgmediated cell death, and the occurrence of cell wall appositions (CWA) only in Mlg responses is detailed in the text. (B) Definition of the Ndr-1 locus suggests that resistance to both bacterial and oomycete pathogens can share common steps. Note that wild-type Eds 1 function is required for resistance to some, but not all, isolates of Peronospora parasitica, and one of several Pseudomonas Syringae aur genes

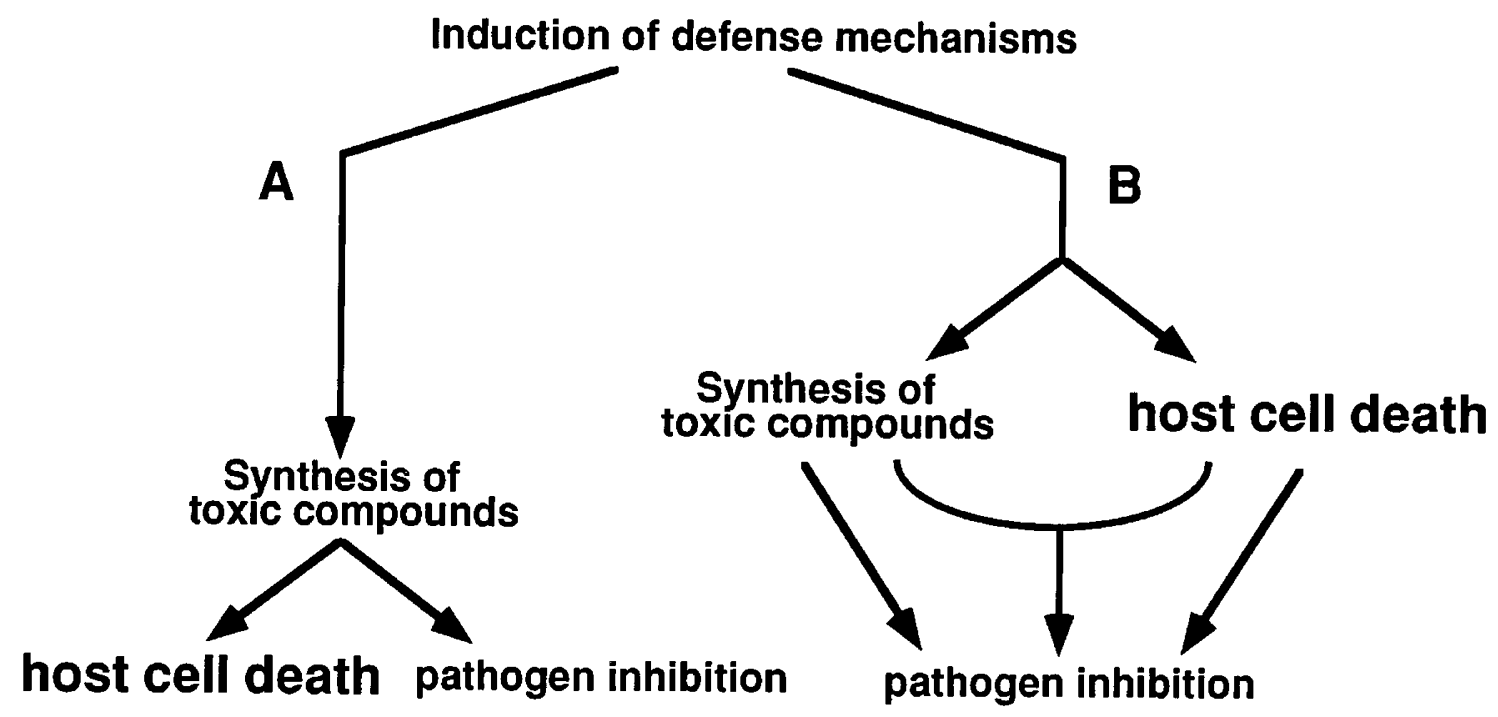

Figure 3 Possible mechanisms leading to the HR. Because many of the plant defense products are also toxic for the plant cell (ROIs, phytoalexins, SA), they could be directly responsible for the death of the host cells $(\mathbf{A})$. However, the possible uncoupling of cell death and other defense responses suggests that they act in parallel pathways, with possible cross-talk (B) 
camalexin, is still able to mount an HR to bacterial pathogens (Glazebrook and Ausubel, 1994). This suggests that camalexin is not necessary for the induction of the HR. Moreover, defense gene mRNA accumulation can be found in the absence of HR, with kinetics and amplitude similar to those observed during the HR (Jakobek and Lindgren, 1993; Schröder et al, 1992). These results further suggest that the initial signaling pathway can fork and give rise to at least 2 branches: one activates the synthesis of phytoalexins and defense proteins while the other one specifically results in the cell death (Figure 3B). Accordingly, Rustérucci et al (1996) used a purified fungal elicitin and cultured tobacco cells to show that the induction of lipid peroxidation and cell death were dependent on the generation of ROls while phytoalexin synthesis was not.

\section{Protectant mechanisms and anti-cell death pathways}

Potential ROI protectant mechanisms include anti-oxidant enzymes such as superoxide dismutase, catalase, glutathione peroxidase, glutathione S-transferase and polyubiquitin. Expression of these genes occurs concomitantly with cell death and $\mathrm{H}_{2} \mathrm{O}_{2}$ may play a role in their induction (Levine et al, 1994, 1996; see below). The induction of these protectant mechanisms, in contrast to the induction of defense genes and cell death, can be independent of $\mathrm{Ca}^{2+}$ signaling (Levine et al, 1996). This further suggests that the induction of defense genes, cell death and anti-oxidant protectant mechanisms are probably controlled by divergent pathways.

Because uncontrolled cell death would lead to deleterious damage at the tissue level, plants apparently have evolved anti-cell death pathways. These pathways may be different than the ones existing in animals, since transgenic tobacco plants carrying the $\mathrm{Bcl}-\mathrm{X}_{\mathrm{L}}$ gene do not show altered response to the TMV virus or to $P$. syringae (Mittler et al, 1996). Functional homologues of the animal anti-cell death dad-1 gene (Gallois et al, 1997; Sugimoto et al, 1995) have recently been found in maize, rice and Arabidopsis, but their involvement in the HR remains to be established. Additionally, plant proteins with conserved domains of the animal ced-9/Bcl-2 protein family have yet to be described.

The best evidence that anti-cell death pathways exist in plants comes from the existence of propagation class cell death control mutants (Isd1 and IIs1). The recent finding that the IIs1 mutant from maize encodes a probable dioxygenase (Gray et al, 1997) raises the possibility that this gene is involved in detoxification of oxidized phenolic compounds such as salicyclic acid (SA). SA can promote cell death (Naton et al, 1996; Shirasu et al, 1997) and considerable levels of SA accumulate during the HR (Eneydi et al, 1992). Therefore L/s1 could act as a suppressor of cell death by scavenging SA or a related phenolic compound. Another good candidate for a negative regulator of both cell death and damping of basal level expression of disease resistance pathways is the Isd1 gene from Arabidopsis. Isd1 mutants exhibit a lowered threshold to trigger $\mathrm{HR}$, and an inability to control HR once it is initiated. The Isd1 mutation defines a gene encoding a novel zinc-finger protein (Dietrich et al, 1997). Thus LSD1 could act as a transcriptional regulator of cell death effectors.

In sum, the induction of $\mathrm{HR}$ involves several plant signals generated in the plant plasma membrane (ROIs, ion fluxes). These signals seem to converge into a few genetically and pharmacologically separable pathways. Subsequently, defense genes, ROI protectant mechanisms and cell death can be induced via divergent pathways (Figure 1).

\section{Is HR the ultimate response triggered by the plant?}

Although the HR is often associated with disease resistance, there are also examples where HR is not causal to resistance. In this respect, barley $\mathrm{mlo}-, \mathrm{M} / \mathrm{g}$ - and Mla-mediated resistances to Erysiphe graminis f.sp. hordei have proven to be an incomparable model. This obligate biotrophic fungus causes powdery mildew. Recessive mlo alleles confer resistance to nearly all races of $E$. graminis f.sp. hordei without development of an HR. Despite the absence of cell death during this resistance response, there may be a link between resistance and deregulated cell death in mlo plants. One pleitropic effect of mlo alleles is to trigger spontaneous cell death in the absence of pathogen. The development of foliar lesions in mlo plants under certain conditions suggests that one stimulus (fungus) does not trigger cell death while others (e.g. low temperatures; Wolter et al, 1993) can. Moreover, the analysis of a large number of $\mathrm{mlo}$ alleles established a correlation between the frequency of necrosis under pathogen-free conditions and the effectiveness of resistance (cited in Büschges et al, 1997). Thus HR may represent the final step in a chain of increasingly severe cellular defense reactions, and this step is simply not reached during mlo-dependent resistance reactions. The mlo phenotype may further indicate a threshold necessary to engage the HR pathway, as was mentioned above for Isd1. In this scenario, the wild-type Mlo gene could function to down regulate a low level, constitutive defense response. Mlo encodes a probable transmembrane protein with no homologues in animal gene databases (Büschges et al, 1997).

Further evidence for differential thresholds activating different $R$ genes is provided by comparison of barley Mlg and Mla function. HR is observed during Mlg-directed response of barley to an incompatible fungal isolate, but is probably not causal for resistance. The interaction between tomato and the fungus Cladosporium fullvum could be another example in which HR may not be causal to resistance (Hammond-Kosack and Jones, 1994). In contrast, HR is a key component of Mla-mediated resistance (Bushnell, 1981). In Mlg barley plants HR appears after the induction of a first set of defense responses, namely cell wall apposition which stops fungal penetration (CWA; Görg et al, 1993). CWA do not form during Mla-mediated responses. It is thus interesting to note that the rar1 mutation, which abolishes Mla-mediated HR, does not suppress Mlg-mediated HR (Peterhänsel et al, 1997). Thus, in Mlg-based resistance, the HR may result 
from overall signal levels passing a threshold. By contrast, in Mla-based resistance this threshold requires Rar1 function for commitment to $\mathrm{HR}$ and is reached before, or independent of, CWA formation. Thus the pathways triggering $\mathrm{HR}$ in Mlg and Mla plants may be independent (see above; Figure 2A). In a case similar to Mlg resistance, cell death only occurs after what appeared to be an unsuccessful penetration attempt that induced a first set of defense reactions (Meyer and Heath, 1988) during incompatible interactions between cowpea and the fungus Erysiphe cichoracearum.

Thus, although HR is sometimes not causal for disease resistance, it appears that HR represents the final stage invoked by plants to resist infection. A threshold seems to be necessary for irrevocable commitment to $\mathrm{HR}$, while the transcriptional activation of defense responses can be activated below this threshold.

\section{Pathogen lifestyles and cell death}

Because pathogens have developed various strategies for growth and reproduction, the requirements for cell death may depend on the nature of the plant-pathogen interaction. The impact of the HR may also vary depending on the lifestyle of the pathogen. In this respect, two parameters should be considered: whether the parasite is intra- or extra-cellular, and whether it is a biotrophic, hemibiotrophic or necrotrophic pathogen. In addition, pathogens use at least three strategies in order to efficiently colonize their hosts. First, if they do not produce any signal molecule recognized by the host, they can evade detection. Second, in the presence of such molecules, they can actively attempt to avoid further triggering of the defense responses (suppression). Third, they can co-opt the plant defense responses by purposely killing the plant cell (negation). Only the last two strategies are presented here because of their consequences for the host cell.

\section{Biotrophic and obligate pathogens}

Viruses are intracellular obligate parasites and need the host cell machinery in order to replicate. Thus cell death of the invaded cell appears to be a good means of blocking multiplication of the pathogen. Because it also results in the mechanical isolation of the infected cell from the neighboring cells, the HR could prevent further viral spread. Yet, by taking a random sample from the literature, Fraser (1990) could find that more than $65 \%$ of the viral resistance genes were not associated with an $\mathrm{HR}$, but rather with reduced multiplication of the virus or total immunity (e.g. the potato Ry gene against PVY; Baker and Harrison, 1984). Thus, HR is not the major resistance mechanism used by plants to protect themselves against viruses.

Biotrophic and hemibiotrophic fungal pathogens develop specialized structures called haustorium which invade the tissue and salvage nutrients. This haustorium penetrates the cell wall and establishes an active interface consisting of the plasma membranes of both the fungus and a living host cell where the uptake of nutrients takes place. In this type of parasitism, the pathogen needs living host cells for its development. Therefore death of the invaded cells could deprive the pathogen of nutrients. Accordingly, in many cases HR precedes growth arrest and death of the incoming pathogen at the haustorial developmental stage of the fungus (Bennett et al, 1996; Bushnell, 1981; Chen and Heath, 1991; Naton et al, 1996). In such cases, HR could cause pathogen death, or the mechanism which kills the plant cells could also kill the pathogen. However, there are also situations where $\mathrm{HR}$ is thought to occur too late to be the causal event for resistance (e.g. Barley M/g resistance gene discussed above; Görg et al, 1993; Koga et al, 1990).

The overall plant defense response is easily inducible (Brederode et al, 1990; Hammond-Kosack and Jones, 1996), and it is surprising that in many cases they are not activated by fungal infection. Fungal pathogens may avoid detection by not producing any effective signal molecule recognized by the plant. Alternatively, they may not produce enough of the signals critical for efficient triggering of the defense responses (Kamoun et al, 1997). This seems unlikely given the mechanical and physiological stresses that a fungus causes in order to colonize its host. In addition, biotrophic fungal pathogens seem to actively inhibit host cell death to prevent the infected cells from dying (e.g. green islands induced by virulent pathogens in otherwise senescing leaves; Johal et al, 1995b). Several reports have demonstrated that some hemibiotrophic pathogens can also suppress defense response activation. This phenomenon parallels well characterized cases in animal diseases caused by viruses, where virus gene products suppress cell death pathways during the multiplication phase (Shen and Shenk, 1995). A large number of fungal-derived molecules suppressing plant defense responses are known (Kunoh, 1995; Yamamoto, 1995). Here we will only mention two of them where the potential plant targets have been identified. The pea pathogen Mycosphaerella pinodes produce glycopeptides, supprescins A and $B$, able to partially suppress defense responses (Shiraishi et al, 1991). Supprescin B may affect the signaling pathway leading to resistance by inhibiting plasma membrane $\mathrm{H}^{+}$-ATPase (Kato et al, 1993). In the interaction between potato and Phythopthora infestans, an Hypersensitivity Inhibiting Factor (HIF) was identified. This HIF, a $\beta, 1-3$ glucan, suppresses cell death and HIF from virulent isolates is more active than HIF from avirulent ones (Doke and Tomiyama, 1980; Maniara et al, 1984). Doke (1985) showed that the HIF suppresses NADPH-dependent ROI production. Thus biotrophic pathogens can suppress the host defense response to successfully invade their host. Figure 4A provides a possible model for the mechanisms of action of such suppressors.

\section{Necrotrophic pathogens}

Necrotrophic pathogens are largely extracellular parasites or may also develop intracellular structures. They usually possess all the enzymatic activities required to utilize the extracellular matrix of the plant cells as a nutrient source. Moreover, they often trigger nutrient leakage from the host cells and are able to live from dead tissues. Thus, the role of host cell death, and which partner it ultimately benefits, 
is questionable in this type of interaction. Nevertheless, development of an HR in these interactions is associated with $R$ gene action. This might reflect the fact that the pathways leading to resistance are linked to those resulting in HR (see Figure 1 and above). In this scenario, HR may simply be the consequence of simultaneous activation of cell death and defense response pathways. Alternatively, cell death and the associated cellular decompartmentalization could provoke the release of toxic compounds (phytoalexins) accumulated in the vacuoles and precede the arrest of the pathogen. Finally, the desiccation process accompanying the HR may generate an anti-microbial environment (Bestwick et al, 1995). Because cell death per se may be insufficient to

\section{A. Suppression}
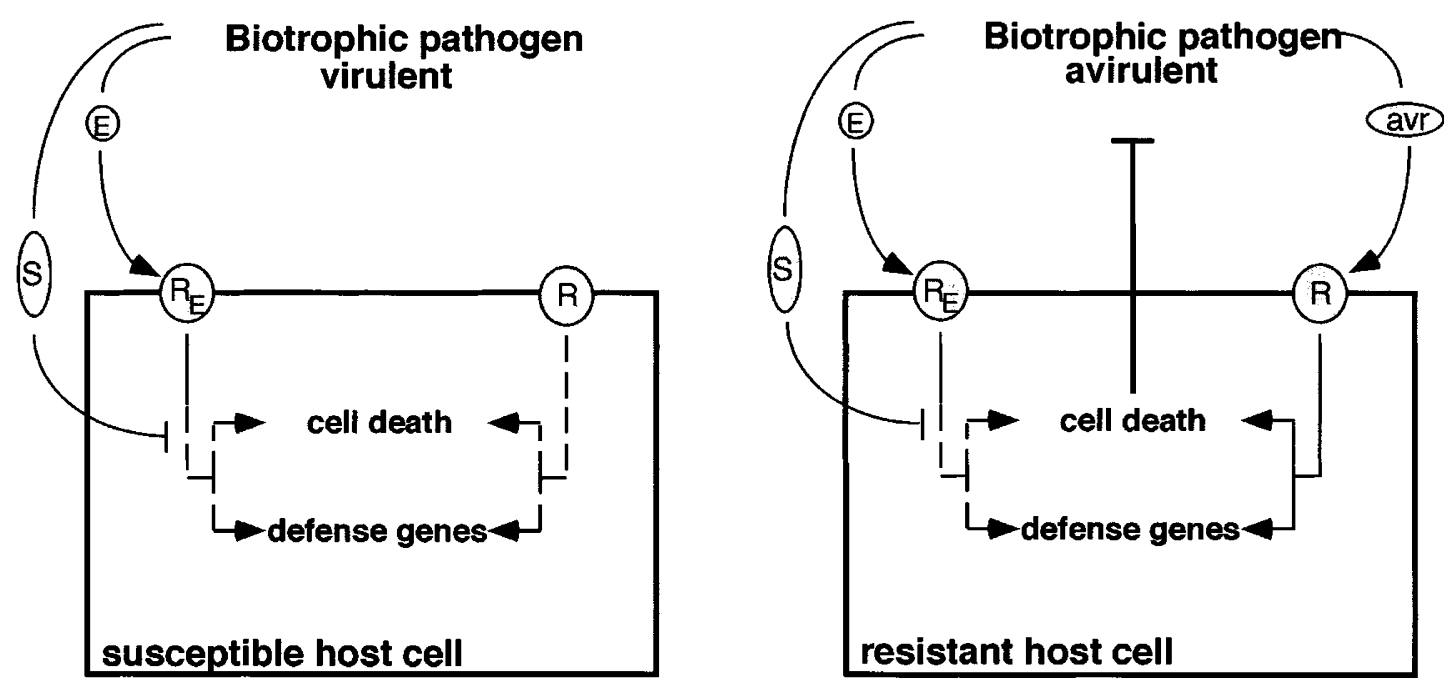

\section{B. Negation}
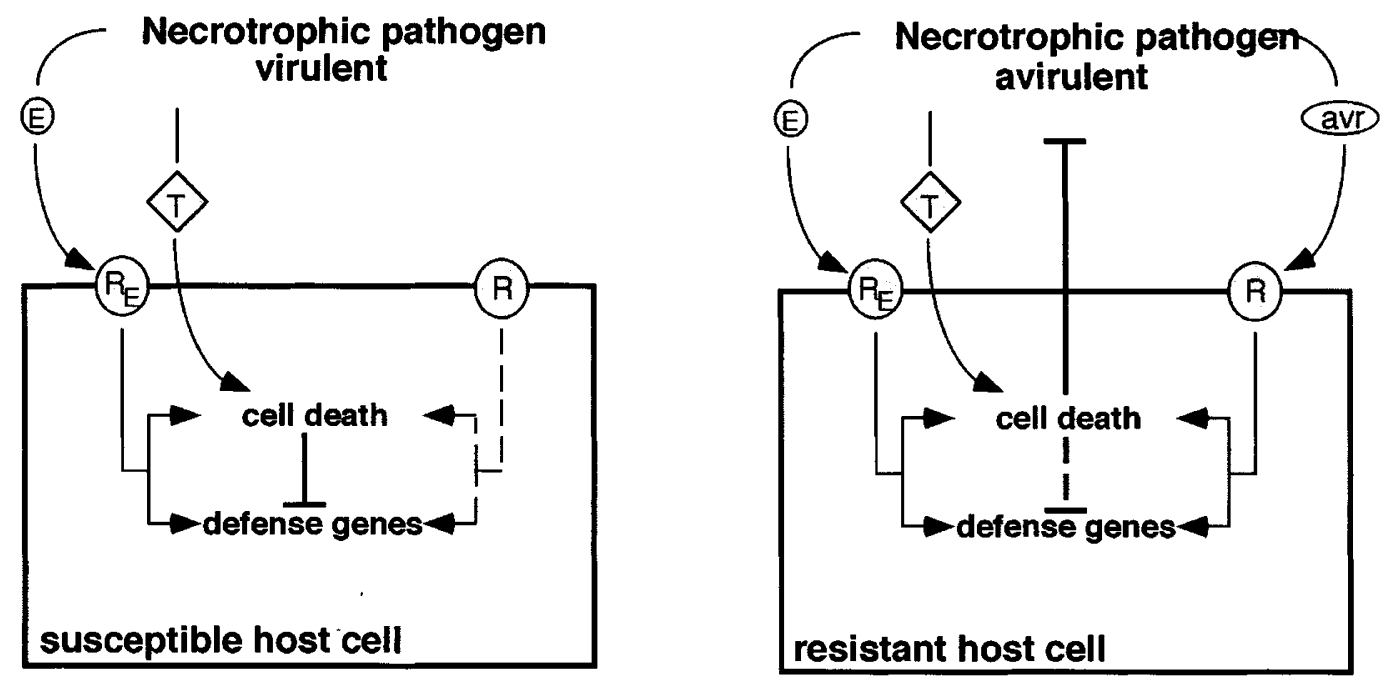

Figure 4 Suppression and negation of the plant defenses. The gene-for-gene specific and elicitor-mediated pathways have been indicated separately but could be identical. Solid lines and dashed lines respectively indicate that the pathway is on or off. E: elicitor; RE: elicitor receptor; avr: avirulence signal; R: resistance gene product; S: suppressor; T: toxin. Arrows indicate positive regulation, flat arrowheads indicate negative regulation. Thick bar with flat arrowhead indicates a successful disease resistance response. (A) Suppression. In the absence of avirulence signals (susceptible host cell), the production of a suppressor molecule can inactivate the induction of the plant defenses by non-specific elicitors. Then in the presence of specific recognition of avirulence signals by $R$ products (resistant host cell), the host cell triggers defense mechanisms despite the inhibiting effect of the suppressor. (B) Negation. In the absence of avirulence signals (susceptible host cell), the production of a molecule (e.g. toxin) impairs the host's ability to respond to elicitors that trigger the defense response. Then in the presence of specific recognition of avirulence signals by $R$ products (resistant host cell), the host cell coordinates an appropriate defense response which overcomes toxinmediated negation 
halt necrotrophic growth, overall coordination of defense responses and $\mathrm{HR}$ is important.

It is also conceivable that a necrotrophic pathogen may utilize a plant cell death pathway (in order to negate the defense responses by purposely killing the cells) to its own advantage, since dead cells are a good growth substrate for such a parasite (Figure 4B; Johal et al, 1995a). Again, animal viruses use similar strategies in order to spread in the infected organism (Shen and Shenk, 1995). A good example of such a strategy could be illustrated by the AALtoxin which, although leading to disease when secreted onto a susceptible host, triggers cell death morphologically reminiscent of apoptosis (Wang et al, 1996; Gilchrist, 1997).

Bacterial pathogens can also co-opt the plant defense responses. Pseudomonas syringae pv syringae produces a cell death-inducing toxin, syringomycin. The target of this small lipopeptide is the plant host plasma membrane where it forms pores (Hutchison et al, 1995). At low concentrations, syringomycin promotes passive membrane ion fluxes reminiscent of the ion fluxes triggered during the HR (Takemoto, 1992). Moreover, some but not all defense responses, are induced by syringomycin (e.g. callose deposition), suggesting that partial induction of host response pathways may be used by $P$. syringae pv syringae in order to negate the full set of resistance responses of the plant. Alternatively, that portion of the defense response triggered by syringomycin may be involved in both HR and disease. The finding by Levine et al (1996) that syringomycin triggers cytologically defined necrosis is not contradictory with this interpretation since, at high concentrations, syringomycin acts as a surfactant and rapidly disrupts plasma membranes (Hutchison et al, 1995).

Necrotrophic pathogens can also suppress plant defenses (in contrast to negate by killing). Coronatine is a chlorosis-inducing toxin produced by $P$. syringae pathovars. It does not induce death of the host cells but shrinkage of the chloroplasts, the consequence of which could be to slow down the metabolism of the attached cells (Palmer and Bender, 1995). It has been observed that mutant strains of Pseudomonas syringae pv tomato which do not produce coronatine induce higher levels of several host defense genes than does the wild-type strain. Thus the function of coronatine could be to suppress the induction of plant defense responses until the bacteria population increases to a level at which it is no longer possible for the plant to limit the infection (Mittal and Davis, 1995). As an additional example, the BZR-toxin produced by Bipolaris zeicola race 3 has a dual mode of action. On rice, it induces cell death and therefore may participate in the negation of the plant defenses. In contrast, the BZR-toxin is not toxic (as measured by the absence of root growth inhibition) and does not trigger cell death on maize or wheat. However, on these plants BZR-toxin induces susceptibility to subsequent infection by normally non-pathogenic fungi (Xiao et al, 1991) and therefore could act by suppressing the host defense responses (Xiao et al, 1992). The mechanisms of action of the BZR-toxin are unknown and it would be interesting to determine how the same molecular component can trigger cell death on one plant (rice) and suppress resistance on others (maize and wheat).

Although these examples do not provide direct evidence that cell death is necessary for resistance, they suggest at least that pathogens try to inhibit it in order to more effectively colonize their host. This inhibition can be performed either by suppression (Figure 4A, biotrophic and necrotrophic pathogens) or by negation (Figure $4 B$, necrotrophic pathogens). These examples also emphasize that a complex network of signals is exchanged during plant-pathogen interactions: the respective interests of each protagonist must be considered in order to assign the role of cell death in disease resistance and disease symptom development. The cell death morphology is the result of the juxtaposition and summing of these different signals. This may explain the diversity of morphologies so far observed during the HR and during the development of disease symptoms.

\section{Is there a social role for the HR?}

Several reports show that expression of defense responses occur in cells surrounding necrotic infection sites (Heitz et al, 1994; reviewed by Kombrick and Somssich, 1995). Using the GUS reporter gene fused to the promoter region of the defense gene chitinase, Samac and Shah (1991) could monitor the induction of this gene after infection. When infected with $P$. infestans, GUS activity was detected in a sharp zone surrounding the necrotic lesions but not around prenecrotic spots. This induction of defense responses in the sharp zone surrounding the HR cells might be essential to restrict pathogen spread. It is known for example that in Tobacco Mosaic Virus-induced HR, the cells immediately beyond the necrotic region contain virus particles (Konate et al, 1982). It was suggested that cells undergoing HR might release signals regulating defense responses in the tissue next to the infection site (Kombrick and Somssich, 1995). In this model, the cells directly in contact with the pathogen overreact to the pathogen, and amplify signals until they commit suicide. This amplification may reflect a runaway cycle where SA and ROls are involved. Indeed $\mathrm{H}_{2} \mathrm{O}_{2}$ can induce SA synthesis (León et al, 1995; Neuenschwander et al, 1995) which, at very high concentrations, can inhibit catalase and other scavenging enzymes (Chen et al, 1993), potentiating further accumulation of $\mathrm{H}_{2} \mathrm{O}_{2}$ (Shirasu et al, 1997).

Cell death may shut down further amplification and trigger signals to neighboring cells. Levine et al (1994) used an experimental design where infected cells were separated from uninfected ones by a dialysis membrane, and showed that $\mathrm{H}_{2} \mathrm{O}_{2}$ can function as a short distance signal. The local oxidative burst in response to infection triggered induction of Glutathione S-transferase but not cell death in the uninfected cells. Thus, although the authors did not examine the induction of other defense genes in this experiment, they could demonstrate the existence of a communication system between uninfected and infected cells. Recently, a diffusible signal able to induce several defense genes (e.g. sesquiterpene cyclase, chitinases, but not PR-1) has been identified after treatment of tobacco 
cells with the cell death inducing elictin cryptogein (Chappell et al, 1997). The detection of superoxide production at the lesion margin of the Arabidopsis Isd1 mutant is another indication that dying cells are triggering cell non-autonomous signals to the neighboring cells (Jabs et al, 1996). Therefore, besides its role in the infected cells, the HR may be used to coordinate the defense responses in neighboring cells (local resistance).

Plants have developed a broad-range secondary resistance known as Systemic Acquired Resistance (SAR). The SAR pathway confers non-specific heightened and prolonged levels of resistance in uninoculated tissues to secondary infections by a broad range of pathogens (reviewed by Ryals et al, 1996). Salicyclic Acid has been shown to play a central role in the establishment of the SAR in at least Arabidopsis and tobacco (Gaffney et al, 1993; Delaney et al, 1994). SAR is biologically triggered by both avirulent and virulent pathogens that cause cell death (as a result of the HR or disease symptoms). Therefore there might be a correlation between cell death and the establishment of SAR. However, if the tissue inoculated by a necrotizing pathogen is removed before the onset of macroscopic cell death, SAR is still observed in systemic inoculated tissues (Smith et al, 1991). In this experiment, the presence of macroscopic lesions was the criteria used for the presence of cell death and it is possible that microscopic cell death had occurred without any visible symptoms (as initiation of the HR and its magnitude may be separable; Hammond-Kosack et al, 1996). Thus, cell death appears to be necessary to trigger the SAR.

\section{Concluding remarks}

The HR is an intrinsically programmed process. However, because of the great diversity of triggers (Dangl et al, 1996; Jones and Dangl, 1996) and morphologies of the cell deaths (Heath, 1980), there are probably several ways in which a cell may die. It does not seem that apoptosis as traditionally defined is a strict paradigm for the HR. The attacked cell and its neighbors are probably not receiving the same signals in both quantity and quality (Levine et al, 1994). In animals, the severity of the initial signal can determine whether the cells undergo necrosis or apoptosis (Bonfoco et al, 1995) and the same could be true in the case of the HR. Thus both apoptosis and necrosis could occur within a single HR region (Kosslack et al, 1996). Plant pathologists still need to establish criteria and find strict markers (if such exist) to differentiate between cell death resulting from environmental or metabolic perturbation and cell death resulting from the activation of the internal HR program. However, the morphological characterization of the HR may be difficult due to the rapidity at which the cellular modifications occur (Freytag et al, 1994). Genetic approaches and cloning of plant genes (such as the genes responsible for the disease lesion mimic phenotypes and $R$ gene suppressors) will shed new light on the mechanisms involved in regulating and executing the HR. The model depicted in Figure 1 suggests that it should be possible to isolate mutants specifically impaired in their induction of the $\mathrm{HR}$, but not in the induction of the other defense responses.
Genetic dissection of the signal transduction leading to $\mathrm{HR}$ is underway and has already suggested that various signal pathways exist. These may or may not converge (Parker et al, 1996; Century et al, 1995; Peterhänsel et al, 1997). The HR also results from a complex interplay of signals from both the plant and the pathogen. The latter can sometimes interfere with these processes in order to successfully colonize the plant (Figure 4). A better understanding of pathogenicity factors and their targets in the host are necessary to interpret the phenomena observed in the challenged plants.

It does not seem that $\mathrm{HR}$ is always necessary for resistance (Fraser, 1990; Wolter et al, 1993). Rather coordination between the different induced mechanisms is required for successful resistance. Cell death during the HR appears to be part of a continuous process where different pathways cross talk. This is also suggested by the fact that in their attempt to isolate mutants with enhanced disease susceptibility, Glazebrook et al (1996) isolated several mutants affected in their resistance to normally avirulent pathogens (nim1/ndr1: Cao et al, 1994; Delaney et al, 1995). Moreover, many of the maize lesions mimics mutants display lesions resembling disease symptoms rather than HR, suggesting that there is also host genetic control of disease symptom development (Johal et al, 1995b). Hence cell death associated with disease symptoms and HR probably share common mechanisms and study of susceptibility will probably give us new insights into resistance mechanisms.

\section{Acknowledgements}

J-B Morel is supported by a pre-doctoral fellowship from the French Ministry of Education and Research (MENESRIP). Research in the Dangl laboratory is supported by grants from the NSF, the DOE Division of Basic Energy Bioscienes and the USDA-NRICGP. We thank Dr. John M McDowell for critical reading of the manuscript.

\section{References}

Agrios GN (1988) Plant Pathology. London: Academic Press

Atkinson MM and Baker CJ (1989) Role of the plasmalemma $\mathrm{H}^{+}$-ATPase in Pseudomonas syringae-induced $\mathrm{K}^{+} / \mathrm{H}^{+}$exchange in suspension-cultured tobacco cells. Plant Physiol. 91: 298-303

Baker $\mathrm{H}$ and Harrison BD (1984) Expression of genes for resistance to potato virus $Y$ in potato plants and protoplasts. Ann. Appl. Biol. 105: 539-545

Baker CJ and Orlandi EW (1995) Active oxygen in plant pathogenesis. Annu. Rev. Phytopathol. 33: 299-321

Bennett M, Gallagher M, Fagg J, Bestwick C, Paul T, Beale M and Mansfield J (1996) The hypersensitive reaction, membrane damage and accumulation of autofluorescent phenolics in lettuce cells challenged by Bremia lactucae. Plant J. 9: $851-865$

Bent AF (1996) Plant disease resistance genes: function meets structure. Plant Cell. 8: $1757-1771$

Bestwick CS, Bennett MH and Mansfield JW (1995) Hrp mutant of Pseudomonas syringaepv phaseolicolainduces cell wall alterations but not membrane damage leading to the hypersensitive reaction in Lettuce. Plant Physiol. 108: 503-516

Bonfoco E, Krainic D, Ankarcrona M, Nicotera P and Lipton SA (1995) Apoptosis and necrosis: two distinct events induced, respectively, by mild or intense insults with $\mathrm{N}$-methyl-D-aspartate or nitric oxid/superoxide in cortical cell cultures. Proc. Natl. Acad. Sci. USA. 92: 7162-7166 
Bradley DJ, Kjellbom and Lamb CJ (1992) Elicitor- and wound-induced oxidative cross-linking of a proline-rich cell wall protein: a novel, rapid defense response. Cell 70: $21-30$

Brederode FT, Linhorst HJM and Bol JF (1990) Differential induction of acquired resistance and PR gene expression in tobacco by virus infection, ethephon treatment, UV light and wounding. Plant Mol. Biol. 17: 11171125

Büschges R, HollricherK, Panstruga R, Simons G, Wolter M, Frijters A, van Daelen R, van de Lee T, Groenendijk J, Töpsch S, Vos P, Salamini F and Schultze-Lefert P (1997) The barley Mlogene: a novel trigger of plant pathogen resistance. Cell 88: $695-705$

Bushnell WR (1981) Incompatibility conditioned by the Mla gene in powdery mildew of barley: the halt in cytoplasmic streaming. Phytopathology 71 : 1062-1066

Cao H, Bowling SA, Gordon AS and Dong X (1994) Characterization of an arabidopsis mutant that is nonresponsive to inducers of systemic acquired resistance. Plant Cell 6: 1583-1592

Century KS, Holub EB and Staskawicz BJ (1995) NDR1, a locus of Arabidopsis thaliana that is required for disease resistance to both bacterial and a fungal pathogen. Proc. Natl. Acad. Sci. USA 92: 6597-6601.

Chappell J, Levine A, Tenhaken R, Lusso M and Lamb C (1997) Characterization of a diffusible signal capable of inducing defense gene expression in tobacco. Plant Physiol. 113: 621-629.

Chen CY and Heath MC (1991) Cytological studies of the hypersensitive death of cowpea epidermal cells induced by basidiospores-derived infection by the cowpea rust fungus. Can. J. Bot. 69: 1199-1206

Chen Z, Silva H and Klessig DF (1993) Active oxygen species in the induction of plant systemic acquired resistance by salicyclic acid. Science 262: $1883-1886$

Dangl JL (1992) Regulatory elements controlling developmental and stress induced expression of phenylpropanoid genes. In: Plant Gene Research, Vol. 8, Genes Involved in Plant Defense. Boller T and Meins F. (eds.), Springer Verlag, Vienna/ New York, pp. 303-326

Dangl JL (1995) Pièce de résistance: novel classes of plant disease resistance genes. Cell 80: 363-366

Dangl JL, Dietrich RA and Richberg MH (1996) Death don't have no mercy: cell death programs in plant-microbe interactions. Plant Cell. 8: 1793-1807

Delaney T, Uknes S, Vernooj B, Friedrich L, Weymann K, Negrotto D, Gaffney T, GutRella M, Kessmann H, Ward E and Ryals J (1994) A central role of salicyclic acid in plant disease resistance. Science 266: 1247-1250

Delaney T, Friedrich L and Ryals J (1995) Arabidopsis signal transduction mutant defective in chemically and biologically induced disease resistance. Proc. Natl. Acad. Sci. USA. 92: 6602-6606

Dietrich RA, Delaney TP, Uknes SJ, Ward ER, Ryals JA and Dangl JL (1994) Arabidopsis mutants simulating disease resistance response. Cell 77: $565-577$

Dietrich RA, Richberg MH, Schmidt R, Dean C and Dangl JL (1997) A novel Zincfinger protein is encoded by the Arabidopsis $L S D 1$ gene and functions as a negative regulator of plant cell death. Cell 88: $685-694$

Doke $\mathrm{N}$ (1985) NADPH-dependent $\mathrm{O}_{2}$ - generation in membrane fractions isolated from wounded potato tubers inoculated with Phytophthora infestans. Physiol. Plant Pathol. 27: $311-322$

Doke N and Tomiyama K (1980) Suppression of the hypersensitive response of potato tuber protoplasts to hyphal wall components by water soluble glucans from Phytophthora infestans. Physiol. Plant Pathol. 16: 177-186

Ebel J and Cosio EG (1994) Elicitors of plant defense responses. Int. Rev. Cytol. 148: $1-36$

Eneydi AJ, Yalpani N, Silverman P and Raskin I (1992) Localization, conjugation and function of salicyclic acid in tobacco during the hypersensitive reaction to tobacco mosaic virus. Proc. Natl. Acad. Sci. USA. 89: 2480-2484

Fraser RSS (1990) The genetics of plant-virus interactions: mechanisms controlling host range, resistance and virulence. In: Recognition and Response in PlantVirus Interactions, Fraser RSS, (ed.), Berlin: Springer-Verlag, pp. 71-93

Freialdenhoven A, Scherag B, Hollricher K, Collinge DB, Thordal-Christensen H and Schulze-Lefert P (1994) Nar-1 and Nar-2, two loci required for Mla ${ }_{12}$ specified race-specific resistance to powdery mildew in Barley. Plant Cell. 6: $983-994$

Freialdenhoven A, Peterhänsel C, Kurth J, Fritz Kreuzaler and Schulze-Lefert P (1996) Indentification of genes required for the function of non-race-specific m/o resistance to powdery mildew in barley. Plant Cell. 8: 5-14
Freytag S, Arabatzis N, HahlbrockK Kand SchmelzerE (1994) Reversible cytoplasmic rearrangements precede wall apposition, hypersensitive cell death and defenserelated gene activation in potato/Phytophthora infestans interactions. Planta 194: $123-135$

Fukuda H (1997) Programmed cell death during vascular system formation. Cell Death Differ. 4: 684-688

Gaffney T, Friedrich L, Vernooij B, Negrotto D, Nye G, Uknes S, Ward E, Kessmann H and Ryals J (1993) Requirement of salicyclic acid for the induction of systemic acquired resistance. Science 261: 754-756

Gallois P, Makishima T, Hecht V, Despres B, Laudié M, Nishimoto T and Cooke R (1997) An Arabidopsis thaliana cDNA complementing a hamster apoptosis suppressor mutant. Plant Cel. in press

Gilchrist DG (1997) Mycotoxins reveal connections between plants and animals in apoptosis and ceramide signaling. Cell Death Differ. 4: 689-698

Glazebrook J and Ausubel FM (1994) Isolation of phytoalexin deficient mutants of Arabidopsis thaliana and their interactions with bacterial pathogens. Proc. Natl. Acad. Sci. USA. 91: 8955-8959

Glazebrook J, Rogers EE and Ausubel FM (1996) Isolation of Arabidopsis mutants with enhanced disease susceptibility by direct screening. Genetics 143: $973-$ 982

Glazener JA, Orlandi EW and Baker CJ (1996) The active oxygen response of cell suspensions to incompatible bacteria is not sufficient to cause hypersensitive cell death. Plant Physiol. 110: 759-763

Goodman RN and Novacky AJ (1994) The Hypersensitive reaction in plants to pathogens. A resistance phenomenon. St. Paul, MN: APS Press

Görg R, Hollricher K and Schulze-Lefert P (1993) Functional analysis and RFLP-mediated mapping of the Mlg resistance locus in barley. Plant J. 3 : $857-866$

Gray J, Close PS, Hantke SS, McElver J, Briggs SP and Johal GS (1997) A novel suppressor of cell death in plants encoded by the $L / s 1$ gene of maize. Cell in press

Greenberg JT, Guo A, Klessig DF and Ausubel FM (1994) Programmed cell death in plants- A pathogen-triggered response activated coordinately with multiple defense functions. Cell 77: $551-563$

Greenberg JT (1996) Programmed cell death: A way of life for plants. Proc. Natl. Acad. Sci. USA. 93: $12094-12097$

Groom QJ, Torres MA, Fordham-Skelton AP, Hammond-Kosack KE, Robinson NJ and Jones JDG (1996) RbohA, a rice homologue of the mammalian gp91phox respiratory burst oxidase gene. Plant J. 10: $515-522$

Hammond-Kosack KE and Jones JDG (1994) Incomplete dominance of tomato Cf genes for resistance to Cladosporium fulvum. Mol. Plant-Microbe Interact. 7: $58-70$

Hammond-Kosack KE, Jones DA and Jones JDG (1994) Identification of two genes required in tomato for full $\mathrm{Cf}$-9-dependent resistance to Cladosporium fulvum. Plant Cell. 6: 361-374

Hammond-Kosack KE and Jones JDG (1996) Resistance gene-dependent plant defense responses. Plant Cell. 8: 1773-1791

Hammond-Kosack KE, Silverman P, Raskin I and Jones JDG (1996) Race-specific elicitors of Cladosporium fulvum induce changes in cell morphology and the synthesis of ethylene and salicyclic acid in tomato plants carrying the corresponding Cf disease resistance gene. Plant Physiol. 110: 1381-1394

Hadfield KA and Bennett AB (1997) Programmed senescense of plant organs. Cell Death Differ. 4: 662-670

He SY, Huang HC and Collmer A (1993) Pseudomonas syringae pv syringae Harpin: a protein that is secreted via the hrp pathway and elicits the hypersensitive response in plants. Cell 73: $1255-1266$

HeSY,BauerDW, Collmer A and Beer SV (1994) Hypersensitive response elicited by Erwinia amylovora requires active plant metabolism. Mol. Plant-Microbe Interact. 7: 289-292

Heath MC (1980) Reaction of nonsuscepts to fungal pathogens. Ann. Rev. Phytopathol. 18: 211-236

Heitz T, Fritig B and Legrand M (1994) Local and systemic accumulation of pathogenesis-related proteins in tobacco plants infected with tobacco mosaic virus. Mol. Plant-Microbe Interact. 7: 776-779

Hu G, Richter TE, Hulbert SH and Pryor T (1996) Disease lesion mimicry caused by mutations in the rust $r p 1$ resistance gene. Plant Cell. 8: 1367-1376

Hutchison ML, Tester MA and Gross DC (1995) Role of biosurfactant and ion channelforming activities of syringomycin in transmembrane ion flux: a model for the mechanism of action in the plant-pathogen interaction. Mol. Plant-Microbe Interact. 8: 610-620 
Jabs T, Dietrich RA and Dangl $\mathrm{JL}$ (1996) Initiation of runaway cell death in an Arabidopsis mutant by extracellular superoxide. Science 273: 1853-1856

Jabs T, Colling C, Tschöpe M, Hahlbrock K and Scheel D (1997) Elicitor-stimulated ion fluxes and reactive oxygen species from the oxidative burst signal defense gene activation and phytoalexin synthesis in Parsley. Proc. Natl. Acad. Sci. USA. in press

Jakobek JL and Lindgren PB (1993) Generalized induction of defense responses in Bean is not correlated with the induction of the hypersensitive reaction. Plant Cell. 5: $49-56$

Johal GS, Gray J, Gruis D and Briggs SP (1995a) Convergent insights into mechanisms determining disease and resistance response in plant-fungal interactions. Can. J. Bot. 73 (suppl. 1): S468-S474

Johal GS, HulbertSH and Briggs SP (1995b) Disease lesion mimics of maize: a mode for cell death in plants. BioEssays 17: 685-693

Jones AM and Dangl JL (1996) Logjam at the Styx: programmed cell death in plants. Trends Microbiol. 1: 114-119

Jones JDG (1997) A kinase with keen eyes. Nature 385: 397-398

Kamoun S, van West $P$, de Jong AJ, de Groot KE, Vleeshouwers VGAA and Govers $F$ (1997) A gene encoding a protein licitor of Phytophthora infestans is downregulated during infection of potato. Mol. Plant-Microbe Interact. 10: 13-20

Kato T, Shiraishi T, Toyoda K, Saitoh K, Satoh Y, Tahara M, Yamada T and Oku H (1993) Inhibition of ATPase activity in pea plasma membranes by fungal suppressors from Mycosphaerella pinodes and their peptide moieties. Plant Cell Physiol. 34: 439-445

Koga H, Bushnell WR and Zeyen RJ (1990) Specificity of cell type and timing of events associated with papilla formation and the hypersensitive reaction in leaves of Hordeum vulgare attached by Erysiphe graminis f.sp. hordei. Can. J. Bot. 68 : 2344-2352

KombrickE and Somssich IE (1995) Defense responses of plants in cells surrounding necrotic infection sites. Adv. Bot. Res. 21:1-34

Konate G, Kopp M and Fritig B (1982) Multiplication du virus de la mosaïque du tabac dans des hôtes systémiques ou nécrotiques: approaches biochimiques à l'étude de la résistance hypersensible aux virus. Phytopath. Z. 105: 214-225

Kosslack RM, Chamberlin MA, Palmer RG and Bowen BA (1996) Apoptosis and necrosis in adjacent root cortical cells precede the defense response in soybean ROOT NECROSIS mutants. J. Hered. 87: 415-422

Kunoh H (1995) Host-parasite specificity in powdery mildews. In: Pathogenesis and Host Specificity in Plant Disease. Histopathological, Biochemical, Genetic and Molecular Basis. Vol. II Eukaryotes. Kohmoto K, Singh US and Singh RP. (eds.) Pergamon, pp. 239-246

Leister RT, Ausubel FM and Katagari F (1996) Molecular recognition of pathogen attack occurs inside of plant cells in plant disease resistance specified by the Arabidopsis genes RPS2 and RPM1. Proc. Natl. Acad. Sci. USA. 93: $15497-$ 15502

León J, Lawton MA and Raskin I (1995) Hydrogen peroxide stimulates salicyclic acid biosynthesis in tobacco. Plant Physiol. 108: 1673-1678

Levine A, Tenhaken R, Dixon R and Lamb C (1994) $\mathrm{H}_{2} \mathrm{O}_{2}$ from the oxidative burst orchestrates the plant hypersensitive response. Cell 79: 583-593

Levine A, Pennell RI, Alvarez ME, Palmer R and Lamb CJ (1996) Calcium-mediated apoptosis in plant hypersensitive disease resistance response. Curr. Biol. 6 : 427-437

Loh YT and Martin GB (1995) The Pto bacterial resistance gene and Fen insecticide sensitivity gene encode functional protein kinases with serine/threonine specificity. Plant Physiol. 108: 1735-1739

Low PS and Merida JR (1995) The oxidative burst in plant defence-Function and signal transduction. Physiol. Plant. 96: 533-542

Maniara G, Laine R and Kúc J (1984) Oligosaccharides from Phytophthora infestans enhance the elicitation of sequiterpenoid stress metabolites. Physiol. Plant Pathol. 24: 177-186

Martin GB, Brommonschenkel SH, Chunwongse J, Frary A, Ganal MW, Spivey RS, Wu T, Earle ED and Tanksley SD (1993) Map-based cloning of a protein kinase gene conferring disease resistance in tomato. Science 262 : $1432-1436$

May MJ, Hammond-Kosack KE and Jones JDG (1996) Involvement of reactive oxygen species, glutathione metabolism, and lipid peroxidation in the Cf-genedependent defense response of tomato cotyledons induced by race-specific elicitors of Cladosporium fulvum. Plant Physiol. 110: 1367-1379

Mehdy MC (1994) Active oxygen species in plant defense against pathogens. Plant Physiol. 105: 467-472
Meyer SLF and Heath MC (1988) A comparison of the death induced by fungal invasion or toxic chemicals in cowpea epidermal cells. II. Responses induced by Erysiphe cichoracearum. Can. J. Bot. 66: 624-634

Mittal S and Davis K (1995) Role of the phytotoxin coronatine in the infection of Arabidopsis thaliana by Pseudomonas syringae pv tomato. Mol. Plant-Microbe Interact. 8: $165-171$

Mittler R and Lam E (1995) Identification, characterization, and purification of a tobacco endonuclease activity induced upon hypersensitive response cell death. Plant Cell. 7: 1951-1962

Mittler R, Shulaev V and Lam E (1995) Coordinate activation of programmed cell death and defense mechanisms in transgenic tobacco plants expressing a bacterial proton pump. Plant Cell. 7: 29-42

Mittler R and Lam E (1996) Sacrifice in the face of foes: pathogen-induced programmed cell death in plants. Trends Microbiol. 4: 10-15

Mittler R, Shulaev V, Seskar M and Lam E (1996) Inhibition of programmed cell death in tobacco plants during a pathogen-induced hypersensitive response at low oxygen pressure. Plant Cell. 8: 1991-2001

Naton B, Hahlbrock K and Schmelzer E (1996) Correlation of rapid cell death with metabolic changes in fungus-infected, cultured parsley cells. Plant Physiol. 112: $433-444$

Neuenschwander U, Vernooj B, Friedrich L, Uknes S, Kessmann H and Ryals J (1995) Is hydrogen peroxide a second messenger of salicylic acid in systemic acquired resistance? Plant J. 8: 227-233

Nürnberger T, Nennsteil D, Jabs T, Sacks WR, Hahlbrock K and Schell D (1994) High affinity binding of a fungal oligopeptide elicitor to parsley plasma membranes triggers multiple defense responses. Cell 78: 449-460

Palmer DA and Bender CL (1995) Ultrastructure of tomato leaf tissue treated with the pseudomonad phytotoxin coronatine and comparison with methyl jasmonate. Mol. Plant-Microbe Interact. 8: 683-692

Parker JE, Holub EB, Frost LN, Falk A, Gunn ND and Daniels MJ (1996) Characterization of eds-1, a mutation in arabidopsis suppressing resistance to Peronospora parasitica specified by several different RPP genes. Plant Cell. 8: 2033-2046

Peterhänsel C, Freialdenhoven A, Kurth J, Kolsch R and Schulze-Lefert P (1997) Interaction analyses of genes required for race-specific and broad spectrum resistance to powdery mildew in barley reveal distinct pathways leading to leaf cell death. Plant Cell. in press

Rustérucci C, Stallaert V, Milat M-L, Pugin A, Ricci P and Blein J-P (1996) Relationship between active oxygen species, lipid peroxidation, necrosis and phytoalexin production induced by elicitins in Nicotiana. Plant Physiol. 111: $885-891$

Ryals JA, Neuenschwander UH, Willits MG, Molina A, Steiner H-Y and Hunt M (1996) Systemic acquired resistance. Plant Cell. 8: 1809-1819

Ryerson DE and Heath MC (1996) Cleavage of nuclear DNA into oligonucleosomal fragments during cell death induced by fungal infection or by abiotic treatments. Plant Cell. 8: 393-402

Salmerson JM, Oldroyd GED, Rommens CM, Scofield SR, Kim H-C, Lavelle SR, DahlbeckD and StaskawiczBJ(1996) Tomato Prf is a member of the leucine-rich repeat class of plant disease resistance and lies embedded within the Pto kinase gene cluster. Cell 86: 123-133

Samac DA and Shah DM (1991) Developmental and pathogen-induced activation of the Arabidopsis acidic chitinase promoter. Plant Cell. 3: 1063-1072

Schlumbaum A, Mauch F, Vogeli U and Boller T (1986) Plant chitinases are potent inhibitors of fungal growth. Nature 324: $365-367$

Schröder M, Hahlbrock K and Kombrink E (1992) Temporal and spatial patterns of $1,3-\beta$-glucanase and chitinase induction in potato leaves infected by Phytophthora infestans. Plant J. 2: $161-172$

Scofield SR, Tobias CM, Rathjen JP, Chang JH, Lavelle DT, Michelmore RW and Staskawicz BJ (1997) Molecular basis of gene-for-gene specificity in bacterial speck disease of tomato. Science 274: 2063-2065

Shen $Y$ and Shenk TE (1995) Viruses and apoptosis. Curr. Op. Gen. Dev. 5 $105-111$

Shiraishi T, Yamada T, Oku H and Yoshioka H(1991) Suppressor production as a key factor for fungal pathogenesis. In: Molecular Strategies of Pathogens and Hos Plants. Patil SS, Ouchi S, Mills D and Vance C (eds.) New York: Springer-Verlag, pp. $151-162$

Shirasu K, Nakajima H, Rajasekhar VK, Dixon RA and Lamb C (1997) Salicyclic acid potentiates an agonist-dependent gain control that amplifies pathogen signals in the activation of defense mechanisms. Plant Cell. 9: 261 -270 
Smith JA, Hammerschmidt R and Fullbright DW (1991) Rapid induction of systemic acquired resistance in cucumber by Pseudomonas syringaepv syringaePhysiol. Mol. Plant Pathol. 28: 223-235

Staskawicz BJ, Ausubel FM, Baker BJ, Ellis JG and Jones JDG (1995) Molecular genetics of plant disease resistance. Science 268: 661-667

Sugimoto A, Hozak RR, Nakashima T, Nishimoto T and Rothman JH (1995) dad-1, and endogenous programmed cell death suppressor in Caenorhabditis elegans and vertebrates. EMBO J. 14: 4434-4441

Takemoto JY (1992) Bacterial phytotoxin syringomycin and its interaction with host membranes. In: Molecular Signals in Plant-Microbe Communications. Verma, DPS (ed). CRC Press, Boca Raton, Fla, pp 247-260.

Tang X, Frederick RD, Zhou J, Halterman DA, Jia Y and Martin GB (1997) Initiation of plant disease resistance by physical interaction of AvrPto and Pto kinase. Science 274: 2060-2063

Umemoto N, Kakitani M, Iwamatsu A, Yoshikawa M, Yamaoka N and Ishida I (1997) The structure and function of a soybean $\beta$-glucan-elicitor-binding protein. Proc. Natl. Acad. Sci. 94: 1029-1034

Van den Ackerveken G, Marois E and Bonas U (1996) Recognition of the bacteria protein AvrBs3 occurs inside the host plant cell. Cell 87: 1307-1316

Walbot V, Hoisington DA and Neuffer MG (1983) Disease lesion mimics in maize. In Genetic Engineering of Plants, Kosuge T and Meredith C (eds.) New York: Plenum Publishing Company, pp. 431-442
Wang H, Li J, Bostock RM and Gilchrist DG (1996) Apoptosis: a functional paradigm for programmed plant cell death induced by a host-selective phytotoxin and invoked during development. Plant Cell. 8: 375-391

Ward ER, Uknes SJ, Williams SC, Dincher SS, Wiederhold DL, Alexander DC, AhlGoy P, Métraux J-P and Ryals JA (1991) Coordinate gene activity in response to agents that induce systemic acquired resistance. Plant Cell. 3: 1085-1094

Wolter M, Hollricher K, Salamini F and Schulze-Lefert P (1993) The mlo resistance alleles to powdery mildew infection in barley trigger a developmentally controlled defence mimic phenotype. Mol. Gen. Genet. 239: 122-128

Xiao ZJ, Tsuge T and Doke N (1992) Further evaluation of the significance of BZR toxin produced by Bipolaris zeicola race 3 in pathogenesis on rice and maize. Physiol. Mol. Plant Pathol. 40: 359-370

Xiao ZJ, Tsuge T, Doke N, Nakatsuka S, Tsuda M and Nishimura S (1991) Ricespecific toxins by Bipolaris zeicola race 3; evidence for role as pathogenicity factors for rice and maize plants. Physiol. Mol. Plant Pathol. 38: 67-82

Yamamoto H (1995) Pathogenesis and host-parasite specificity in rusts. In Pathogenesis and Host Specificity in Plant Disease. Histopathological, Biochemical, Genetic and Molecular Basis. Vol. II Eukaryotes. Kohmoto K, Singh US and Singh RP (eds.) Pergamon pp. 203-212

Zhou J, Loh YT, Bressan RA and Martin GB (1995) The tomato gene Pti1 encodes a serine/threonine kinase that is phosphorylated by Pto and is involved in the hypersensitive response. Cell 83: 925-935 